\title{
UNIVERSITY FINANCE IN BRITAIN
}

$\mathrm{T}$ HE annual survey of the academic year 1963-64 by the University Grants Committee* is this year issued as a separate publication and it is proposed to continue this practice in future, partly to avoid delaying the presentation of the statistics. The survey begins by summarizing the changes in organization and membership which followed the acceptance by the Government of recommendations made by the Robbins Committee. (These have since been superseded, at least partly, by subsequent changes under Mr. H. Wilson's administration, though the Committee continues to be responsible to the Secretary of State for Education and Science and not to the Treasury.) It is stated that the Committee on Audio-Visual Aids in Institutions of Higher Education is expected to report in the spring of 1965 and the Committee on Libraries "within the next year or so". A new standing advisory panel on computers with Sir Willis Jackson as chairman was established in conjunction with the Department of Education and Science, "to consider and advise, in the light of available resources, on proposals which are referred to them for the provision of computer facilities and related matters in institutions of higher education". The staff of the Committee had risen to 50 by January 1963 (compared with 22 in January 1953) and, aftor a comprehensive review of organization and procedures in the office, agreement was reached on a new staffing complement. The increase in staff has far outstripped the accommodation available, but it is hoped that the alternative premises secured at 13-14 Park Crescent, London, W.1, will be ready for occupation early in 1965 and suffice for needs in the foreseeable future.

On university expansion to 1967-68, the survey comments that analysis of the replies of the universities to the request sent to them in October 1963 showed that the aggregate total of places offered by 1967-68 was substantially greater than that required to meet the Robbins objective of 197,000 . Discussions on scaling down, involving 35 institutions, were started in January 1964, and completed in February 1964. Following these, the Committee advised the Government as to the addition required to the building starts programme for 1965 , and on May 14, 1964, the Government announced that $£ 54.5$ million would be authorized for building starts in the period January 1, 1965-March 31, 1966. The Committee had also to consider the appropriate procedures for organizing the transition to university status of the colleges of advanced technology and the Heriot-Watt College, Edinburgh. All the colleges concerned agreed to the proposal to appoint Academic Advisory Committees for this purpose, in consultation with the University * University Grants Committee Annual Survey, Academic Year 19631964. (Cmnd. 2571.) Pp. 28. (London: H.M.S.O., 1965.) 1s. 9d. net.
Grants Committee. Membership of these Committees is dealt with in an appendix to the survey. A similar procedure was adopted for the Royal College of Art and the College of Aeronautics.

The survey also recapitulates progress with the ten-year programme of expansion to 1973-74, recording the reconstitution of the New Universities Sub-Committee under Sir John Wolfenden's chairmanship, and the discussions on academic salaries with the National Incomes Commission are also summarized. The Committee has also agreed with the Government on a formula covering the principles which should govern the discontinuance of family allowances to new appointments, promotions, and transfer from one university to another. The University of St. Andrews is setting up, in collaboration with the University Grants Committee, an Academic Advisory Committee for the development of Queen's College, Dundee, as a separate university, and it is expected that the University of Dundee will be inaugurated in October. 1966 , or, at latest, in October 1967. Developments in British Business Schools and management studies, follow: ing the reports of Lord Franks and of Lord Normanbrook's working party, are also summarized.

The Committee has also undertaken, at the Government's request, further enquiries regarding the location of a new medical school and the expansion of existing medical schools, consequent on the recommendations of the Gillie Report and the Platt Report. On July 27, 1964, the Minister of Health announced that the new medical school would be located at the University of Nottingham, with a new teaching hospital of 1,200 beds and an annual entry of 100 students. Ho also stated that, on the advice of the University Grants Committee, existing medical schools would be expanded to increase the annual intake of British-based students by about 150 by October 1966. Early in 1964 the Committee decided to review the existing arrangement for controlling the cost of residential accommodation for university students, and the Committee and the Department of Education and Science are now considering the recommendations of a joint working party appointed for this purpose. Early in 1963 the attention of the universities was directed to some of the possibilities in the application of new building techniques to university building and in particular to the Clasp system which the University of York is adopting in its building programme and modifying for university use. In conjunction with the education departments and the Ministry of Public Building and Works, a working party was set up to consider more rapid and cheaper means of providing student residence in a period of emergency expansion; the results of this survey were communicated to the universities in November 1963.

\section{LONG-TERM ECONOMIC PLANNING FOR GROWTH}

$\mathrm{B}$ ROADSHEET No. 487, issued by Political and Economic Planning* and prepared by G. Denton, summarizes the most urgent conclusions for Britain to $b \theta$ derived from recent experience with institutions, the planning of targets, the balance of payments, incomes policy, fiscal policy and regional policy.

As regards institutions, from their formation early in 1962 to October 1964, the National Economic Development Council and the National Economic Development Office were the chief institutions for long-term economic planning for growth, and considerable progress was mado

* Planning, 31, No. 487 (March, 1965): Planning for Growth. Pp. 75-114. (London: Political and Economic Planning, 1965.) 68. during the period in fulfilling the main purpose of the Council-that of involving both sides of industry with the Government in the formation of economic policy. The main problems encountered by both institutions concerned their position on the edge of the administrative structure and the recruitment of staff. The Council was, in constitution, a typical advisory body but required to influence Government, industry and the Unions in a predetermined direction. It was supported by an Office independent of any Government department, yet in close touch with Whitehall and also with representatives of organizations of industry and with the Trades Union Congress. 
It was its access to confidential official documents which involved restrictions on publication that meant that the National Economic Development Office was neither a part of Government nor an independent research institute: this position was not entirely comfortable. Partly on account of this ambiguous position, there was some difficulty in staffing the Office. Secondments from industry and from the universities were an obvious first step to building up an experienced and highly qualified staff and maintaining an independent position. However, this policy led to some uncertainty about career prospects among the essential core of permanent staff, and there was a high turnover of staff aggravated by uncertainty about the role and future of the organization and by competition from the rapidly expanding universities. The whole organization in 1964 was troubled by four major factors: its ambiguous position in the existing structure of Government; the uncertainties of the staff; speculation about the future organization under either a Labour or a Conservative Government; and the developing economic crisis.

In these circumstances there was a strong case for bringing the economic planning side of the organization inside the Government. To put it within the Treasury would have been an improvement, but the present Government went further in setting up the Department of Economic Affairs. This took over most of the division of the Treasury concerned with economic growth, as well as most of the economic division of the National Economic Development Office, including its head, who became Director-General in charge of economic planning in the new Department, thus obtaining a clearly defined position in Whitehall. Advantages, however, were seen in keeping the industrial division of the Office in its independent position. The Broadsheet points out that it is far too soon to assess the way in which the new organization for planning growth will operate.

On the target announced by the Government in the autumn of 1964 , of a rate of growth of 3.8 per cent per annum, the Broadsheet comments that the move towards greater flexibility is a much-needed reassurance, in view of the new emphasis on direction. Furthermore, there is much to be said now for the sensible proposition that the Government should examine and publish the consequences of more than one rate of growth.

The Broadsheet concludes that both the National Economic Development Council and its Office can now be seen to have suffered in their early days from an excess of enthusiasm. Britain now has an indigenous organization but the problem of enthusiasm is as real as ever, and keenness to get an incomes policy quickly may lead the Government into more trouble, while there is some danger that the desire for a fuller utilization of resources in the immediate future may lead to some wrong decisions on regional policy. Secondly, the experience in planning for growth has emphasized the need for much flexibility and it is unlikely that the organization established in October 1964 will prove to be ideal in every respect. Changes in structure and in personnel may be needed and the Government must be ready to adjust the plans and targets in the light of economic events. Britain needs a consistent long-term view of the economy, but this does not mean that the plan with a single-target rate of growth of national output, broken down into targets for individual sectors, can and must be maintained. Flexibility is particularly desirable when the outcome of policies is very uncertain as, above all, in the field of incomes policy. It is also necessary to avoid the danger that the attempt to plan the growth of the economy over certain time periods that are convenient for drawing up forecasts may result in propagating a new and broad-but not broad enoughconventional wisdom. Four to six years may be a convenient period to plan in trying to superimpose a longerterm view of economic policy than has so far been applied, but what is good for the economy in 1970 may not be so desirable in 1975 or 1980 . Plans on the French or the National Economic Development Council model are better characterized as medium rather than as long term. A third requirement for the new approach to planning for growth is that the policy of the Government should be clear.

\section{MEDICAL RESEARCH IN THE BRITISH CARIBBEAN}

HE tenth annual meeting of the Standing Advisory
Committee for Medical Research in the British
Caribbean was held in Barbados during April 3-6. His
Excellency the Governor, Sir John Stow, formally opened
the meeting with Sir Grey Messiah, president of the
Senate, as chairman. Addresses were given by Mr. Da-
Costa Edwards, the Minister of Health, Dr. K. L. Stuart,
reader in medicine, University of the West Indies, and
Dr. E. T. C. Spooner, dean of the London School of
Hygiene and Tropical Medicine.
The main topic of the scientific meeting was "Infectious
and Parasitic Disease", and forty-two papers were read:
twenty-two from Jamaica, nine from Trinidad, three from
Barbados, two from British Guiana, one each from the
U.S. Virgin Islands and British Honduras, and four
from the United States. Two papers from British Honduras
and Curaçao wero read in title.
Dr. W. G. Downs of the Rockefeller Foundation was
chairman of the first session on virus diseases. Important
observations on the role of viruses in the aetiology of
respiratory infections in the tropics were reported in
papers from the Department of Microbiology, and the
Trinidad Regional Virus Laboratory, University of the
West Indies. Both influenza A and B virus were isolated
during epidemic periods in Jamaica, though adenovirus,
para-influenza and respiratory syncytial viruses were also
isolated from clinical eases. Twenty-five strains of the latter virus were isolated from throat swabs of infants and young children during a recent severe outbreak of bronchiolitis and pneumonia in Trinidad. The use of fluorescent antibody techniques in the early and specific diagnosis of microbial infections was reported by Dr. A. E. Urquhart and Prof. L. S. Grant. A latex agglutination test was described by Dr. Likar and Prof. Grant for the detection of arbovirus antibodies where haemagglutination techniques may not be easily applicable. Drs. J. O. Mason, T. Frothingham, A. Spielman and Prof. T. H. Weller, of Harvard University, reported that successful inoculation of a chick embryo cell culture with Sindbis virus was obtained when infected Aëdes aegypti were allowed to feed on the medium. This culture system may be useful in the investigation of arbovirus ecology, and several possible applications of this technique were explored in the discussion following this paper. Drs. K. MacKenzie, J. Carberry and D. Luck reported on an outbreak of acute poliomyelitis in 1964, which was confined to Kingston, the capital of Jamaica, where no mass immunization was carried out during 1964. Ninety per cent of the patients were less than four years old and 78 per cent had not received any polio vaccine. Paralysis occurred in 84 per cent of the cases and poliovirus Type 1 was isolated in more than one-third of all cases. The age incidence of the disease and its occurrence among a nonimmunized population, especially in infants less than a 